\title{
林窗对长苞冷杉自然更新幼苗存活和生长的影响
}

\author{
刘 庆 \\ (中国科学院成都生物研究所,成都 610041)
}

摘 要 长苍冷杉 ( Abies georgei) 林是我国西南亚高山针叶林的重要类型之一, 分布于海拔 $3200 \sim 4200 \mathrm{~m}$ 。目前对 于该森林林窗对树苗更新的调节还很少了解。通过 1997 2000 年对 20 个林窗的连续观测调查, 研究了滇西北白 马雪山自然保护区西坡亚高山长苞冷杉林林窗大小和林窗位置对自然更新幼苗存活和生长的影响。长苞冷杉针 叶林林窗大小分布为, 面积大于 $100 \mathrm{~m}^{2}$ 的大林窗占 $20 \%$ 左右, 中等林窗面积为 $50 \sim 100 \mathrm{~m}^{2}$, 占 $35 \%$ 左右，小林窗面 积小于 $50 \mathrm{~m}^{2}$ 占 $45 \%$ 左右。 4 个生长季节的连续观测结果表明 :林窗与林下非林窗内的幼苗大小和幼苗存活数量 差异明显。林窗由小到大 单位面积内的自然更新苗木数量逐渐增加, 大林窗中更新苗为小林窗的 1.5 倍左右, 而 林下的更新苗很少, 0.5 ind: $10 \mathrm{~m}^{-2}$ 。中等林窗和小林窗内的幼苗数量在从南到中心到北的位置上几乎没有明显 的差异; 大林窗中存在由南到北的位置差异, 更新幼苗数量逐渐增加。从更新幼苗的生长来看, 中等林窗内的幼 苗, 高度最大、生长最快, 定居阶段的平均年高生长为 $(7.8 \pm 0.5) \mathrm{cm} \mathrm{a}^{-1}$,小林窗次之, 大林窗和林下幼苗个体最 小, 生长最慢。更新幼苗的基径随林窗大小的变化与高度变化相似。进一步从林窗位置来看, 中、小林窗幼苗大小 和年平均高生长量几乎无位置差异, 大林窗则由南到北, 幼苗由大变小, 年高生长量逐渐减低。从幼苗存活数量、 生长大小来看, 中等林窗大小是长苞冷杉幼苗更新的适宜面积, 这为该类型退化亚高山针叶林恢复提供了一定的 参考。

关键词 长苞冷杉 林窗 自然更新 幼苗 存活 生长 亚高山针叶林

\section{THE EFFECTS OF GAP SIZE AND WITHIN GAP POSITION ON THE SURVIVAL AND GROWTH OF NATURALLY REGENERATED ABIES GEORGEI SEEDLINGS}

\author{
LIU Qing \\ ( Chengdu Institute of Biology, Chinese Academy of Sciences , Chengdu 610041, China)
}

\begin{abstract}
The survival and growth of Abies georgei seedlings growing in forest canopy gaps was investigated over a 4-year period on the Baima Snow Mountain in northwest Yunnan Province , China. Of the total gaps surveyed in A. georgei forests , $45 \%$ were small (gap area $<50 \mathrm{~m}^{2}$ ), 35\% were medium sized $\left(50-100 \mathrm{~m}^{2}\right.$ ) and $20 \%$ were large $\left(>100 \mathrm{~m}^{2}\right)$ gaps. Seedling growth rates, survivorship, abundance and size were measured and compared among the three different sized gaps and under the closed forest canopy and within gaps according to their position (north, south and center) in each gap. The seedlings all originated from natural seed rain. The results showed that there were significant differences in the size and number of seedlings among the different sized gaps and understorey. There were 1.5 times more seedlings in larger gaps than in smaller ones and very few seedlings $\left(0.5\right.$ ind $\left.: 10 \mathrm{~m}^{-2}\right)$ were found in the understory. The survival of $A$. georgei seedlings within gaps tended to increase from south to north positions within the larger gaps, whereas survivorship did not vary within the small and medium sized gaps. Seedling size, in terms of both height and basal diameter, in the different sized gaps was as follows : medium $>$ small $>$ large $>$ understorey. Relative growth rates showed a similar pattern. The average annual growth in height was $(7.8 \pm 0.5) \mathrm{cm}$ in medium gaps. Furthermore, size and annual relative height growth of seedlings did not differ significantly among positions within the medium and small gaps, but seedling height peaked in the southern position of large gaps and de-
\end{abstract}

Received : 2002-12-04 Accepted : 2003-10-02

Foundation item : The study was financially supported by the State Key Basic Research and Development Plan (G2000046802-05) , the Key Project of Knowledge Innovation Program of the Chinese Academy of Sciences (KSCX1-07-02-02), the Talent Plan of the Chinese Academy of Sciences and the Chinese Academy of Sciences for Key Project (KZ951-A1-104-03-02)

Author thanks Mr. Pang Jin-Hu , Mr. Sheng Cai-Yu at Xishuangbanna Tropical Botanical Garden , CAS , and Dr. Wu Ning , Dr. Bao Wei-Kai at Chengdu Institute of Biology, CAS , Mr. Zhongyong Bili and Gema Jiachuo at Baima Snow Mountain for their help and the support of the field works in Baima Snow Mountain Natural Reserve. Special thanks to Prof. T. V. Callaghan at Sheffield Centre for Arctic Ecology, the University of Sheffield, UK for valuable reviews and modification of expression in English. 
clined towards the center and north edges. Seedling establishment was greater in gaps than under the closedcanopy. Due to adaptation to light conditions, relative growth rates of seedlings were greatest in medium sized gaps but were relatively low in regions of the large gaps that had greater exposure to direct solar radiation as well as in small gaps that were shaded and received little direct solar radiation. Finally , based on observed changes in survival and growth of seedlings over four growing seasons, the author suggests that medium sized forest canopy gaps provide the best habitat for regeneration of $A$. georgei seedlings.

Key words Abies georgei , Forest gap , Natural regeneration , Seedling , Survival , Growth , Subalpine coniferous forest

Abies georgei forest is one of the major subalpine coniferous forests in the southwest of China, and distribute on subalpine range from 3200 to $4200 \mathrm{~m}$ above sea level (Liu et al . ,2001a). The subalpine coniferous forest has important ecological roles such as conserving water and soil , and biological diversity , and is accredited as the significant ecological barrier of the regions in eastern edges of Tibet Plateau and the upper reaches of the Yangtze River (Liu et al . , 2001b ; Liu , 2002). Unfortunately, the forest has been severely destroyed and few of primitive vegetation are preserved in the past decades years. At present, most of the subalpine coniferous forests in southwestern China are in different states of degradation. Thus, it is very urgent to restore the damaged these forest ecosystems.

Forest gaps created by the death of one or more trees are critical in the community dynamics of many forest types ( Pickett \& White, 1985). It is very important for natural regeneration ( e.g. establishment and growth of different tree species) of forests (Canham , 1990 ; Cintra \& Horna , 1997). Nevertheless, the role of canopy gaps in forest development is only partially understood. The role has been documented both in temperate forests and in tropical forests (Brokaw , 1985 ; Poulson \& Platt , 1989 ; Runkle ,1982 ; Zang , 1998) , but has paid much less attention to coniferous forests , especially to subalpine coniferous forest (Kenneth ,1992 ; Li , 1990 ; Xia et al. , 1996) .

The invasion of shade-tolerant species to gaps appears to be associated with gaps created ( Gray \& Spies , 1996) , but it is not clear whether it is a response to gap size or to micro-environments within canopy gaps created by mortality of dominant trees. Thus it is important to know how canopy gaps influence early phase of the natural regeneration of old-growth coniferous subalpine forests. Establishment and growth of forest trees should be correlated with gap size and within-gap position and such patterns are seen in many forests (Poulson \& Platt , 1989 ; Runkle , 1982 ; Gray \& Spies , 1996 ; Brandani et al . , 1988).

The controls on tree seedling establishment in relation to canopy gaps within subalpine coniferous forests in southwestern China are poorly understood. Therefore , the purpose of this paper is to 1 ) determine whether the es- tablishment and growth of the Abies georgei seedlings are affected by gap size and within-gap position, i.e. , what fate of the naturally regenerated seedlings in different sized gaps, and 2) whether the survival of Abies georgei seedling was better in gap than non-gaps (understorey). The survey described in this paper is part of a larger study ; future papers will demonstrate the effects of seed germination in forest canopy gaps .

\section{Materials and Methods}

\subsection{Study site}

The study was conducted at the west slope of Baima Snow Mountain Natural Reserve $\left(27^{\circ} 47^{\prime}-28^{\circ} 36^{\prime} \mathrm{N}, 98^{\circ}\right.$ $57^{\prime}-99^{\circ} 21^{\prime} \mathrm{E}, 3800-4000 \mathrm{~m}$ above sea level) in northwestern Yunnan, China. The observation reported here was made between September 1997 and October 2000. Annual rainfall at study site is $650.5 \mathrm{~mm}$, annual evaporation is $566.1 \mathrm{~mm}$ and relative humidity is $82 \%$. Annual mean temperature is $4.7{ }^{\circ} \mathrm{C}$, the extreme minimum temperature is $-18.6{ }^{\circ} \mathrm{C}$ in January and extreme maximum temperature is $15.8{ }^{\circ} \mathrm{C}$ in August (Yunnan Province Academy of Forestry Planning , 1989). The content of soil organic matter of the subalpine coniferous forest is $2.82 \%-3.65 \%$, and soil $\mathrm{pH}$ is $5.6-5.9$.

Subalpine coniferous forests form the natural vegetation of this zone and still cover considerable parts of the site. The vegetation belt (from 3500 to $4200 \mathrm{~m}$ asl. wide) is dominated by Abies georgei in tree layer, Rhododendron sp. in shrub layer and moss on the ground layer ( Liu et al . ,2001a) . A. georgei is able to regenerate naturally in the study site.

\subsection{Species}

Abies georgei is one of the major evergreen coniferous tree species in subalpine zone in the southwest of China. A. georgei forest is natural and often mixed with other species of Abies and Picea in tree layer in the study area , and tree density averages $320-460$ adult trees per hectare. Height of the canopy often was $8-18 \mathrm{~m}$, sometimes up to $25 \mathrm{~m}$, and diameter at breast height ( $D B H$ ) ranges from 12 to $36 \mathrm{~cm}$.

\subsection{Experimental design}

Twenty gaps were measured with diameter (lengths of the major and minor axes measured between tree crown edges) in the study area, and selected 15 different sized 
gaps for the seedlings experiment in September 1997. These gaps were created by the death of one or more trees or from disturbance due to human activity in the study site in terms of cutting and so on. Understorey vegetation is almost the same in the gaps.

This study was designed to follow the fate of seedlings originating from natural seed rain in different sized natural gaps. Three sizes of these gaps, with two replicates of each gap size, were chosen in the Abies georgei forest stands. Measured and chosen gaps size was divided into three scales : small $\left(<50 \mathrm{~m}^{2}\right)$, medium (50 $\left.-100 \mathrm{~m}^{2}\right)$ and large $\left(>100 \mathrm{~m}^{2}\right)$. All chosen forest gaps were located in areas with slopes less than $20 \%$ and with relatively identified understorey in each. Three understorey sites equal in area to the large gap size, were randomly established in the stand. Each gap was subdivided into a lot of $6-\mathrm{m}^{2}$ plots. Three within-gap positions (north, south and center) were identified in each gap (Fig. 1).

In late spring or early summer of 1997 , many of the seedlings emerged in the gaps. The individuals of firstyear Abies georgei within plots in different sized gaps and control plots was searched and marked with red paint on the basal shoots.

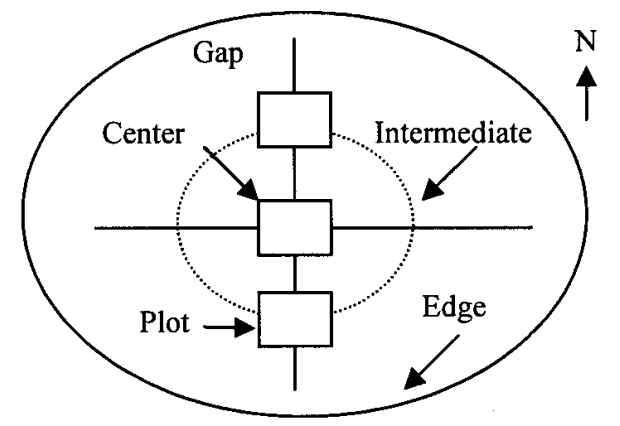

Fig. 1 The plots in canopy gap of subalpine Abies georgei forest

\subsection{Measurements}

Height and basal diameter of first-year seedlings among different sized gaps and control plots were not significantly different according to Tukey's honestly significant difference (Proc One-way ANOVA, SAS Inc. , 1988), i.e. , $(2.6 \pm 0.2) \mathrm{cm}$ of height and $(0.3 \pm 0.04) \mathrm{cm}$ of basal diameter (mean $\pm \mathrm{SE})$. Marked seedlings were revisited in September 1998, 1999 and 2000. Size (i.e. basal diameter and height) of naturally regenerated seedlings of Abies georgei from the 1997 cohort within $2 \mathrm{~m}$ $\times 3 \mathrm{~m}$ of each plot was measured in different sized gaps and the control. Seedlings were considered dead when they were missing, cut at the stem, or entirely lacking green color. At the same time, seedlings were counted in each plot. Seedlings were considered" established" if they were alive at the end of the experiment.
Due to the very low number of naturally regenerated Abies georgei seedlings in the study site, all seedlings from different position in each gap were regarded as overall to calculate for natural regeneration analysis. The effects of gap size and within-gap position on seedling survival , seedling size ( height and basal diameter) and relative height growth ( $R H G$, (final height - initial height)/ 3 years) were determined with one-way analysis of variance (ANOVA) for among four treatments: control, small, medium and large. Results with a probability higher than $p>0.05$ were considered as not statistically significant. All analyses were conducted using SPSS 11.5 for Windows (SPSS Inc. , Chicago , USA).

\section{Results}

\subsection{Gap characteristics}

Most gaps had an elliptical shape , and gap area was calculated using the formula for an ellipse. $A=2 \pi L W /$ 4 , which $L$ and $W$ are the lengths of the major and minor axes. The mean gap area was $82 \mathrm{~m}^{2}$ ( range $16-230 \mathrm{~m}^{2}$; $n=20)$. Canopy gaps were divided into large $(>100$ $\left.\mathrm{m}^{2}\right)$, medium $\left(50-100 \mathrm{~m}^{2}\right)$ and small $\left(<50 \mathrm{~m}^{2}\right)$ gaps , in which there are $45 \%$ of small , 35\% of middle and $20 \%$ of large gaps in Abies georgei forest (Fig. 2).

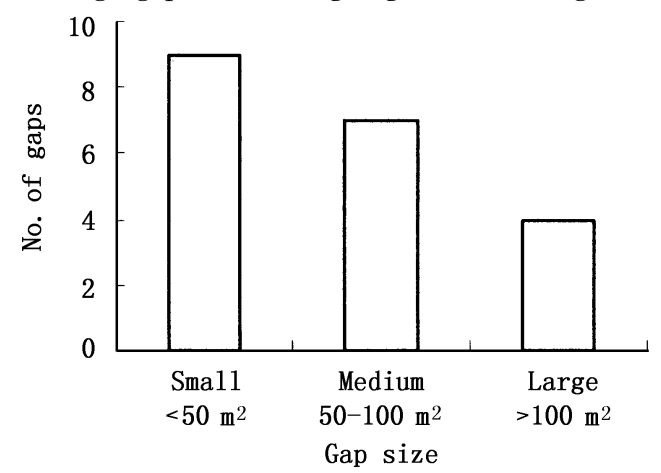

Fig.2 Distribution of gap size at Baima Snow Mountain , Yunnan , China

A total of 20 gaps, in which small $\left(<50 \mathrm{~m}^{2}\right) 9$, medium $(50-100$ $\left.\mathrm{m}^{2}\right) 7$ and large $\left(>100 \mathrm{~m}^{2}\right) 4$

\subsection{Seedling survival}

At the end of the experiment (2000), the difference of survival number of naturally seeded Abies georgei seedlings varied significantly between control (understorey) and canopy gaps $(F=9.37, p<0.05)$. At the beginning of the experiment (1997), Abies georgei seedling density was great in the understorey, whereas the seedling density was small in all gaps, i. e. average 28 individuals in control and 13 individuals in whole gaps per $10 \mathrm{~m}^{2}$, respectively. There were more 1-year and 2-year old Abies georgei seedlings in understorey sites than in the gaps.

However, survival of naturally regenerated seedlings after four growing seasons in gaps is more than in the control, i.e. 0.5 individuals in control and 1.2 individuals per $10 \mathrm{~m}^{2}$ in whole gaps, respectively. The seedlings sur- 
vival was significantly lower in small and medium gaps ( small $\approx$ medium) than in large gaps, and the lowest in control at the end of the experiment. The number of the seedling survival in large gaps was $200 \%$ greater than in control , $100 \%$ and $133 \%$ higher in small and medium gaps.

ANOVA analysis indicated that survival of the seedlings after four growing seasons differed significantly by gap size (Table 1). The survival of Abies georgei seedlings increased with gap size, for example, this change of survival of the seedlings within northern position was showed in Fig. 3. Average survival of the seedlings was approximately 1.5 times in large gaps than small ones at the end of the experiment. In addition , the survival of the seedlings in different within-gap position was also significantly different by different sized gaps (Table 1) .

After four growing seasons (this survival seedlings were also called" establishment" ones), survival of Abies georgei seedlings were significantly different and tended to increase from southern through central to northern positions within large gaps $(F=5.68, p<0.05)$, whereas differences of survival of the seedlings were not significant at different gap positions in small and medium gaps, respectively $(F=1.97, p>0.05$ and $F=3.29, p>$ 0.05 ) (Fig. 4).

Table 1 ANOVA table for significance test the effects of gap size and within-gap position on survival , height , $R H G$ of Abies georgei seedlings after four growing seasons

\begin{tabular}{|c|c|c|c|c|c|c|}
\hline & Source & Sum of squares & $d f$ & Mean square & $F$ & Significance \\
\hline \multirow[t]{2}{*}{ Survival } & Within-gap position & 0.244 & 2 & 0.122 & 8.082 & 0.002 \\
\hline & Gap size & 0.587 & 13 & 0.045 & 2.991 & 0.007 \\
\hline \multirow[t]{2}{*}{ Height } & Within-gap position & 18.742 & 2 & 9. 371 & 14.053 & 0.000 \\
\hline & Gap size & 449.394 & 13 & 34.569 & 51.840 & 0.000 \\
\hline \multirow[t]{2}{*}{$R H G$} & Within-gap position & 0.770 & 2 & 0.385 & 22.287 & 0.000 \\
\hline & Gap size & 98.426 & 13 & 7.571 & 438.405 & 0.000 \\
\hline
\end{tabular}

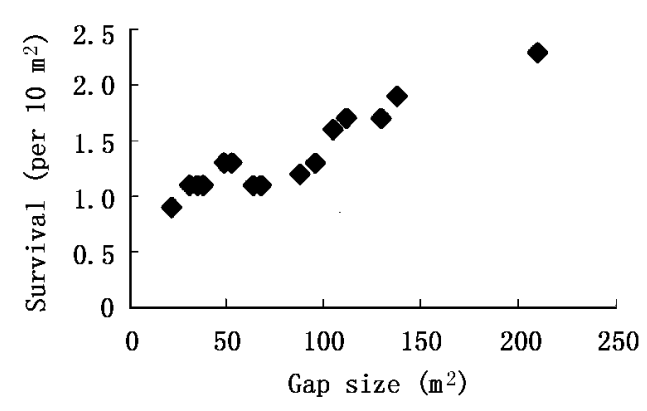

Fig.3 Survival of Abies georgei seedlings after four growing seasons by gap size ( within northern position)

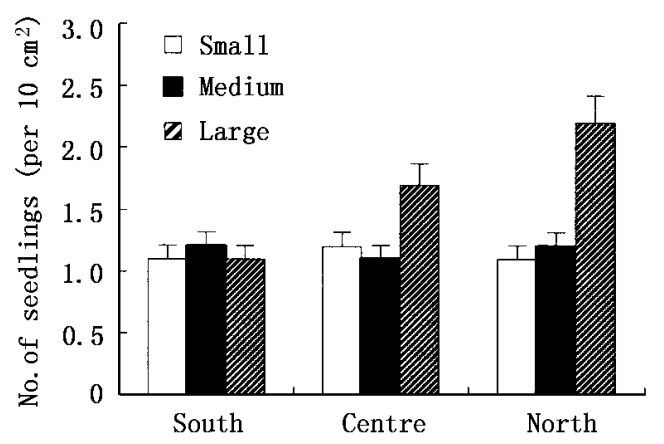

Fig. 4 Survival of natural regeneration after four growing seasons by positions within-gaps

Bars indicate mean $\pm \mathrm{SE}(n=5)$

\subsection{Seedling growth}

Compared with control , gap size had a significant effect on the size of naturally regenerated Abies georgei seedlings in terms of the height, basal diameter and $R H G$ (mean annual height growth) of the seedling after four growing seasons $(F=5.11, p<0.05, F=3.84, p<$ 0.05 and $F=4.27, p<0.05$, respectively).

The effects of gap size and within-gap position on height and RHG of Abies georgei seedlings were significantly different (Table 1 ). The size of naturally regenerated seedlings in different sized gaps varied greatly. For example, distribution of height of Abies georgei seedlings in different sized gaps ( within northern position) was showed in Fig. 5. The largest individuals both in height and basal diameter occurred in medium gaps, immediate individuals in small gaps, the third in size in large gaps and the smallest individuals in control. The average annual $R H G$ changes was medium $>$ small $>$ large $>$ control. The average annual $R H G$ of seedlings in medium gaps was approximate two times of the large gaps, three times of control sites (Table 2).

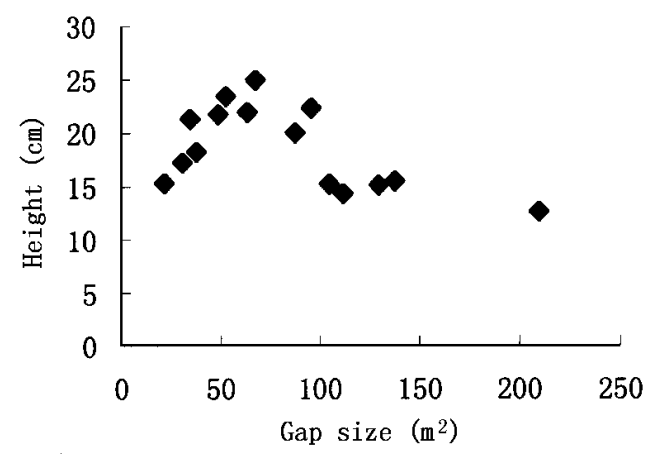

Fig.5 Height of naturally regenerated Abies georgei seedlings after four growing seasons in different sized gaps (within northern position) 
Table 2 Effects of gap size on growth of Abies georgei seedlings after four years of regeneration (numbers are mean $\pm \mathrm{SE}, n=5$ )

\begin{tabular}{lcccc}
\hline Measurement & Small & Medium & Large & Control \\
\hline Height $(\mathrm{cm})$ & $17 \pm 1.4$ & $24.5 \pm 2.7$ & $14.8 \pm 1.9$ & $9.9 \pm 1.2$ \\
Basal diameter $(\mathrm{cm})$ & $2.5 \pm 0.3$ & $2.9 \pm 0.3$ & $2.0 \pm 0.2$ & $1.7 \pm 0.2$ \\
$R H G\left(\mathrm{~cm} \mathrm{a}^{-1}\right)$ & $4.7 \pm 0.2$ & $7.8 \pm 0.5$ & $4.2 \pm 0.4$ & $2.4 \pm 0.1$ \\
\hline
\end{tabular}

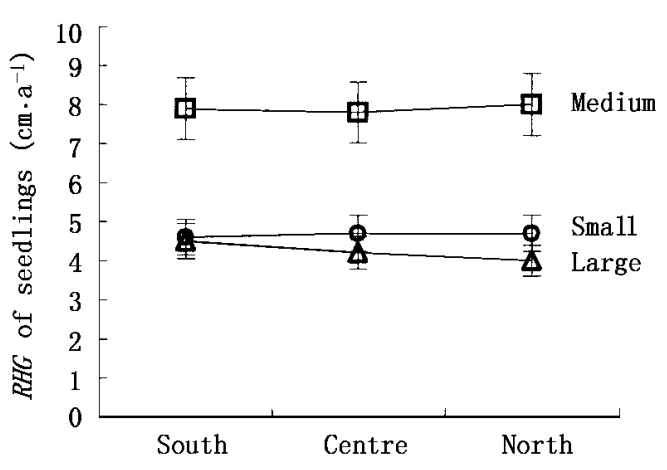

Fig.6 The average annual relative height growth ( $R H G)$ of naturally

regenerated Abies georgei seedlings after four growing seasons on the north-south transects in different sized gaps

$R H G$ is (final height - initial height)/3 years. Bars indicate mean $\pm \mathrm{SE}$ $(n=5)$

Furthermore, if fifteen gaps were divided into three types of sized gaps ( small, medium and large, the same above), the results were found that the average annual $R H G$ of naturally regenerated Abies georgei seedlings was significantly different within-gap positions in large gaps $(F=7.27, p<0.05)$, and were no significantly different in medium and small gaps $(F=0.86, p>0.05$ and $F=2.23, p>0.05$, respectively) at the end of the experiment. The $R H G$ of the seedlings along the north-south transects of the large gaps, declined from the southern parts towards the central and northern parts (Fig. 6).

\section{Discussion}

Although natural regeneration of subalpine coniferous forests in western China was often reported in the past decade ( $\mathrm{Li}, 1990$; Wang \& Xu , 1995 ; Wu , 1999 ; Sichuan Forests Editorial Committee, 1992 ; Liu \& Wu , 2002), this is the first study that examined the process of seedling establishment for Abies georgei over a range of gap size.

The seedlings of Abies georgei is considered being shade-tolerant ( Chinese Forests Editorial Committee, 1999), however, the seedlings in understorey had lower survival rate than that in gaps. High mortality of Abies georgei seedlings in closed-canopy forest in the study occurred during the first and second growing season after emergence. Meanwhile, it is valuable attention that there were a lot of younger Abies georgei seedlings in understorey sites than in the gaps at the early period. It is likely that suitable light levels in the understorey helpful for the seed germination (Chinese Forests Editorial Committee , 1999).
This study showed that greater seedling density occurred in gaps. Establishment of Abies georgei seedlings varied significantly among different sized gaps, but no significantly among within-gap positions in medium and small gaps, while establishment of the seedlings tended to be higher in southern positions of large gaps and establishment of the seedlings was the lowest in control areas. The result is not similar to that of Gray' s study on gap size effects in Douglas-fir forests (Gray \& Spies , 1996). The causes must be studied further in the future. In a word, it is during the seedling establishing stages when most mortality occurs. High mortality at early stages limits the number of recruits a plant population can produce.

Seedling growth response appeared to differ among different sized gaps. Growth rate with gap size are medium $>$ small $>$ large $>$ control. In addition, average annual relative height growth of the seedlings also is varied in different positions in large gaps, that is particularly gradually increase from northern through central to southern positions of gaps, possibly due to suitable light levels and the undense shrub and herb layers in the southern parts of the gaps.

Why was the seedling growth rate greater in medium gap and southern positions of large gaps than those in other gaps and positions? The younger Abies georgei seedlings are shade-tolerant and are adapted to grow in shade condition that is approximate $20 \%$ light levels ( $\mathrm{Liu}, 2002$ ). The environmental conditions (e.g. light , temperature) are different in different sized gaps and within gap positions ( Liu et al . , 2000 ; Wang et al . ,2000 ; Zhang et al., 2001). The seedlings in large gaps were more exposed to direct solar radiation and those in medium and small gaps were shaded to weak solar radiation , and the seedlings of north position in large gaps also were more exposed to direct solar radiation than those of south position (because trees in surrounding gap block off from south solar radiation). The southern edges of large gaps were the only zones that received indirect solar radiation and are shade in this study ( $\mathrm{Liu} \& \mathrm{Wu}, 2002$ ). So growth rate of the seedlings in southern positions was higher than in central and nothern positions in large gaps because of its shade-tolerant trait.

Locations with the greatest survival often had relatively low growth, and vice-versa. This is just the same to that of Gray and Spies (1996) in conifer seedling when working with gap size and position treatments. In understorey, low resource levels (e.g. light) may have limited survival as well as growth. The seedlings at south positions were taller but with lower density, smaller but with 
higher density at north positions in large gaps. Hence, moderate resource levels in shaded gaps may have been sufficient to ensure high growth rates, but not survival. High light levels in exposed gap locations may have led to low growth rates of established seedlings.

This study suggests that gap size and within-gap position are also important determinants for regeneration of Abies georgei forest, canopy gaps in subalpine coniferous forests are important sites for establishment of conifer seedlings, and that medium gap size is favourable area for regeneration of Abies georgei forest based on the changes of survival and growth of seedlings for four growing years in the early period. Abies georgei seedling growth rates in this study were quite low in large gaps and understorey, although relative high survival rates. The medium gaps may be important sites for forest development by allowing abundant establishment and relatively high growth rates of established seedlings because of the greatest $R H G$ and size.

\section{References}

Brandani, A., G. S. Hartshorn \& G. H. Orians. 1988. Internal heterogeneity of gaps and species richness in Costa Rican tropical wet forest. Journal of Tropical Ecology, 4: 99 119 .

Brokaw, N. 1985. Gap-phase regeneration in a tropical forest. Ecology, 66: $682 \sim 687$.

Canham, C. D. 1990. Light regimes beneath closed canopies and treefall gaps in temperate and tropical forests. Canadian Journal of Forest Research, 20: $620 \sim 631$.

Chinese Forest Editorial Committee (中国森林编辑委员会). 1999. Forest of China (Vol. 2) : coniferous forests. Beijing: China Forestry Publishing House. 825 834. (in Chinese)

Cintra, R. \& V. Horna. 1997. Seed and seedling survival of the palm Astrocaryum murumura and the legume tree Dipteryx micrantha in gaps in Amazonian forest. Journal of Tropical Ecology, 13: $257 \sim 277$.

Gray, A. N. \& T. A. Spies. 1996. Gaps size, within-gap position and canopy structure effects on conifer seedling establishment. Ecology, 84: $635 \sim 645$.

Kenneth, P. L. 1992. Pattern of gap-phase replacement in a subalpine, old-growth forest. Ecology, 73: $657 \sim 669$.

Li, C. B. (李承彪). 1990. Ecological study of Sichuan forest. Chengdu: Sichuan Science \& Technology Press. $513 \sim 537$. (in Chinese)

Liu, Q. (刘庆) \& Y. Wu (吴彦). 2002. Effects of gap size on regeneration of subalpine coniferous forests in northwest Yunnan. Chinese Journal of Applied \& Environmental Biology (应用与环 境生物学报), 8: $453 \sim 459$. (in Chinese with English abstract)

Liu, Q. (刘庆) , Y. Wu (吴彦), H. He (何海), N. Wu (吴 宁) \& W. K. Bao (包维楷). 2001a. Community characteristics of Abies georgei forest on the western slope of Baima Snow Mountain in the northwestern Yunnan. Journal of Chongqing Normal University (Natural Science Edition) (重庆师范学院学报 (自然科学版) $), 18(3)$ : 9 14. (in Chinese with English ab- stract)

Liu, Q. (刘庆) , Y. Wu (吴彦) \& H. He (何海). 2001b. Ecological problems of subalpine coniferous forest in the southwest of China. World Science-Technology Research \& Development (世 界科技研究与发展) , 23: $63 \sim 69$. (in Chinese with English abstract)

Liu, Q. (刘庆). 2002. Ecological research on subalpine coniferous forests in China. Chengdu: Sichuan University Press. 1 15. (in Chinese)

Liu, W. J. (刘文杰), Q. J. Li(李庆军), G. M. Zhang(张光 明), J. P. Shi(施济普) \& K. J. Bai(白坤甲)。2000. Microclimatic characteristics of canopy gaps in Shorea chinensis forest in Xishuangbanna. Acta Phytoecologica Sinica (植物生态学 报), 24: $356 \sim 361$. (in Chinese with English abstract)

Pickett, S. T. A. \& P. S. White. 1985. Natural disturbance and patch dynamics: an introduction. In: Pickeet, S.T.A. \& P.S. White eds. The ecology of natural disturbance and patch dynamics. New York: Academic Press. 3 13 .

Poulson, T. L. \& W. J. Platt. 1989. Gap light regimes influence canopy tree diversity. Ecology, 70:553 555 .

Runkle, J. R. 1982. Patterns of disturbance in some old-growth mesic forests of eastern North America. Ecology, 63: 1533 1546.

Sichuan Forests Editorial Committee (四川森林编辑委员会). 1992. Forests of Sichuan. Beijing: China Forestry Publishing House. $237 \sim 251$. (in Chinese)

Wang, J. X. (王金锡) \& J. D. Xu(许金铎). 1995. Ecology and regeneration of cutted blank in alpine and plateau region of the upper reach of Yangtze River. Beijing: China Forestry Publishing House. (in Chinese)

Wang, J. X. (王进欣), Y. P. Zhang(张一平), Y. X. Ma(马 友金簺), Y. H. Liu(刘玉洪), Y. R. Li(李佑荣) \& W. P. Duan(段文平). 2000. Linear character of sunshine of the gap in the artifical forest in Xishuangbanna. Journal of Plant Resources and Environment (植物资源与环境), 9(1) : 27 30. (in Chinese with English abstract)

Wu, N. (吴宁) . 1999. Dynamics of forest gaps in subalpine coniferous forests on the eastern slope Gongga Mountain. Acta Phytoecologica Sinica (植物生态学报), 23: 228 237. (in Chinese with English abstract)

Xia, B. (夏冰), S. A. He (贺善安), T. Lan (兰涛), F. Deng(邓飞) \& G. Yao(姚淦).1996. Canopy gaps in subalpine spruce fir forests of the hills around Bitahai Lake, Yunnan Province. Journal of Plant Resouces and Environment(植物资源 与环境), 5(4): 1 8. (in Chinese with English abstract)

Academy of Forestry Planning of Yunnan Province (云南省林业规 划院). 1989. Yunnan Natural Reserve. Beijing: China Forestry Publishing House. $260 \sim 268$. (in Chinese)

Zang, R. G. (藏润国). 1998. Research advances of gap regeneration dynamics. Chinese Journal of Ecology (生态学杂志), 17 (2) : $50 \sim 58$. (in Chinese with English abstract)

Zhang, Y. P. (张一平), J. X. Wang(王进欣), Y. H. Liu(刘 玉洪) \& Y. X. Ma (马友鋥). 2001. Principle analysis on characteristics of the spatial variation of average air temperature in tropical secondary forest canopy gap. Chinese Journal of Ecology (生态学杂志), 20(2) : 1 4. (in Chinese with English abstract) 